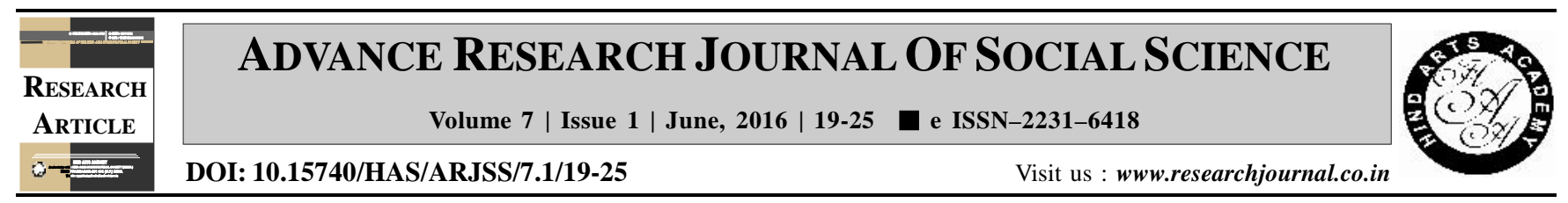

\title{
Role performance of Indian tribal women in agro bio-diversity conservation
}

T.N. Sujeetha* and S. Palaniswamy

Department of Agricultural Extension and Rural Sociology, Tamil Nadu Agricultural University, COIMBATORE (T.N.) INDIA (Email: jenithawalking087@gmail.com)

\author{
ARTICLE INFO : \\ $\begin{array}{lll}\text { Received } & : & 06.02 .2016 \\ \text { Revised } & : & 23.03 .2016 \\ \text { Accepted } & : & 04.05 .2016\end{array}$ \\ KEY WORDS : \\ Index; Tribal women, Bio-diversity \\ Conservation, Role performance
}

HOW TO CITE THIS ARTICLE :

Sujeetha, T.N. and Palaniswamy, S. (2016). Role performance of Indian tribal women in agro bio-diversity conservation. Adv. Res. J. Soc. Sci., 7 (1) : 19-25, DOI: 10.15740/HAS/ARJSS/7.1/19-25.

*Author for correspondence

\begin{abstract}
The role of women in tribal communities is substantial and crucial. They constitute about half the total population but in tribal society women are more important than in other social groups, because they work harder and the family economy and management depends on them. Awais et al. (2009). This study was designed to investigate the role performance of tribal women of the Nilgiris district in farm management. A sample of 180 tribal women was taken as respondents for the study. The results suggest that the Irula tribal women performed roles like cultivating traditional crop varieties (4.30), preservation of forest produce (4.30), livestock maintenance (4.30) and cultivating medicinal plants (4.17) for example Coleus aromaticus, Spilanthus calva, Solanum nigrum, Eclipta prostrate, Withania somnifera. Their high level of role performance in activities like nutrient management for the crops (4.30), utilization of locally available resources (4.30), using farm yard manure (4.17) and watershed management (4.00) were found out.
\end{abstract}

